\title{
Improving teacher quality through classroom action research
}

\section{Nur Amalia ${ }^{a, 1, *}$, Fitni Wilis ${ }^{a, 2}$}

${ }^{a}$ Faculty of Teacher Training and Education, Universitas Muhammadiyah Prof. DR. HAMKA, Jl. Tanah Merdeka No.20, RT.11/RW.2, Rambutan,

Kec. Ciracas, Kota Jakarta Timur, Daerah Khusus Ibukota Jakarta 13830, Indonesia

${ }^{1}$ nuramalia@uhamka.ac.id*; ${ }^{2}$ wilishafi@gmail.com

* Corresponding author

\begin{tabular}{|c|c|}
\hline ARTICLE INFO & ABSTRACT \\
\hline $\begin{array}{l}\text { Article history } \\
\text { Received: 2021-08-29 } \\
\text { Revised: 2021-10-26 } \\
\text { Accepted: 2021-10-28 } \\
\text { Published: 2021-10-28 } \\
\text { Keywords } \\
\text { Teacher quality } \\
\text { Classroom action research } \\
\text { PAUD ‘Aisyiyah teachers }\end{array}$ & $\begin{array}{l}\text { Classroom Action Research Training for Aisyiyah PAUD Central Java Teachers to Improve the } \\
\text { Quality of Learning delivered by the Principal and Teacher Training of PAUD 'Aisyiyah PWA } \\
\text { Central Java, this activity aims to: 1) instill awareness in PAUD 'Aisyiyah teachers on the } \\
\text { importance of Classroom Action Research 2) improve skills prepare proposals for Classroom } \\
\text { Action Research 3) provide assistance related to Classroom Action Research, 4) train teachers to } \\
\text { be able to provide treatment to the subjects studied, so that they experience positive changes. } \\
\text { The methods used in this training are presentations, discussions, case studies. This training } \\
\text { activity was attended by } 142 \text { teachers from PAUD 'Aisyiyah in Central Java. The results of the } \\
\text { service are theoretically successful, this can be seen from the enthusiasm of the training } \\
\text { participants who actively ask questions about the problems they encounter related to the steps } \\
\text { of preparing the CAR proposal, but judging from the practice of preparing the proposal the } \\
\text { results have not been satisfactory, because only } 15 \% \text { of participants can prepare a CAR proposal } \\
\text { properly. and } 33 \% \text { is considered sufficient, while } 52 \% \text { of participants have not succeeded in } \\
\text { compiling a CAR proposal. It is not easy to write CAR, it requires independent effort training from } \\
\text { the teacher concerned to solve the problems faced in PBM. In general, PAUD 'Aisyiyah Central } \\
\text { Java teachers need further assistance in writing Classroom Action Research. }\end{array}$ \\
\hline
\end{tabular}

\section{Kata kunci}

Guru PAUD ‘Aisyiyah

Kualitas guru

Penelitian tindakan kelas
Peningkatan kualitas guru melalui penelitian tindakan kelas. Pelatihan Penelitian Tindakan Kelas Bagi Guru PAUD Aisyiyah Jawa Tengah Untuk Meningkatkan Kualitas Pembelajaran yang disampaikan oleh Kepala Sekolah dan Keguruan PAUD 'Aisyiyah PWA Jawa Tengah, kegiatan ini bertujuan untuk: 1) menanamkan kesadaran pada guru PAUD 'Aisyiyah akan pentingnya Ruang Kelas Penelitian Tindakan Kelas 2) meningkatkan keterampilan menyusun proposal Penelitian Tindakan Kelas 3) memberikan pendampingan terkait Penelitian Tindakan Kelas, 4) melatih guru untuk dapat memberikan perlakuan terhadap mata pelajaran yang dipelajari, sehingga mengalami perubahan yang positif. Metode yang digunakan dalam pelatihan ini adalah presentasi, diskusi, studi kasus. Kegiatan pelatihan ini diikuti oleh 142 guru PAUD 'Aisyiyah di Jawa Tengah. Hasil pengabdian secara teoritis berhasil, hal ini terlihat dari antusias peserta diklat yang aktif bertanya tentang permasalahan yang dihadapi terkait langkah-langkah penyusunan proposal PTK, namun dilihat dari praktik penyusunan proposal hasilnya belum memuaskan, karena hanya $15 \%$ peserta yang dapat menyusun proposal PTK dengan baik. dan 33\% dianggap cukup, sedangkan $52 \%$ peserta belum berhasil menyusun proposal PTK. Penulisan PTK tidak mudah, diperlukan pelatihan usaha mandiri dari guru yang bersangkutan untuk memecahkan permasalahan yang dihadapi dalam PBM. Secara umum guru PAUD 'Aisyiyah Jawa Tengah membutuhkan pendampingan lebih lanjut dalam penulisan Penelitian Tindakan Kelas.
Copyright (C) 2021, Amalia \& Wilis This is an open access article under the CC-BY-SA license 


\section{INTRODUCTION}

The implementation of the education and training program, as an effort to support the Sustainable Development Goals (SDGs) program that has been carried out cannot be separated from the concept of $21^{\text {st }}$-century education (OECD, 2018; Unesco, 2016; Wahyudin, 2018; Yuan et al., 2021), which needs to be prepared from an early age, so that PAUD is in accordance with the demands of $21^{\text {st }}$-century education. PAUD 'Aisyiyah must be a milestone to instill skills children need to have as a provision for the future. Thus, the learning process needs to be designed and structured by adjusting the skills that need to be achieved. The selection of the right approach needs to be a concern, and adjusting the main concepts of the 2013 curriculum, especially those applied to PAUD with an integrative holistic scientific and thematic approach, can be combined with a Science-based learning approach (Ananda \& Abdillah, 2018; Nurdyansyah \& Fahyuni, 2016; Sunardi et al., 2017).

As one of the determining factors for the success of the quality of educational outcomes, teachers must improve their professional quality, in line with rapidly developing scientific and technological advances (Kamamia et al., 2014; Paul \& Jefferson, 2019; Stanciu et al., 2020; Trust et al., 2016), especially during this Covid-19 period (Amalia et al., 2021; Sabilah et al., 2021; Wahyono \& Husamah, 2020; Yakub et al., 2021). This can be done through professional development in various ways and the spirit of resilience that can be trained through the ability to write Classroom Action Research (CAR) proposals as a scientific effort by teachers to solve problems encountered in the teaching and learning process through self-reflection when finding problems in class. The results of reflection as a form of teacher awareness to improve themselves and try to take it through CAR (Syah, 2016; Usman et al., 2021).

CAR report products are formatted into research articles published in scientific articles resulting from simple research as a form of teacher actualization to carry out professional duties (Agustini et al., 2020; Khasinah, 2013; Lateh et al., 2020; Marta, 2020; Oktoviana et al., 2020; Sumiati \& Wijanaraga, 2020; Supriyanto, 2017; Ulianas et al., 2018). CAR results are published in electronic journals and a means for teachers to be digitally literate in the era of information technology as a means of positive communication that is growing rapidly. This is reinforced by Law No. 14 of 2005, which states that a teacher must have pedagogic, personality, social, and professional competencies. The definition of competence, in this case, includes a set of knowledge, skills, and behaviors that must be possessed, internalized, mastered, and actualized by teachers in carrying out their duties.

Teachers are one of the primary keys to determining the success of education, including all processes in it. Qualified teachers will be able to teach well and plan and use appropriate learning strategies so that students will be facilitated to learn efficiently and effectively, improving student achievement (Keiler, 2018; Remesh, 2013; Wollman-Bonilla et al., 2008). Mastery of various strategies and learning models cannot be separated from various activities in the development of the teaching profession. The ability of teachers to research will improve performance in their profession as educators. Qualified teachers can also take advantage of the support of facilities such as teaching material modules, engaging learning media, using varied play while learning strategies, and developing children's fine and gross psychomotor abilities without being burdened with learning materials (Kamamia et al., 2014; Keiler, 2018).

Qualified teachers are not only able to interact well, but also have to update information, be able to develop creativity and innovation, observe, study and analyze problems in their virtual classroom, have curiosity, always make observations, and make themselves a subject of learning (Ahmadi \& Besançon, 2017; Serdyukov, 2017; Wijayati et al., 2019). Efforts to find out about something as an effort to search fortruth, always seek, express, and find the truth like a philosopher. Qualified teachers will impact the quality of output (students), and the quality of schools. The primary basis for the need for CAR to be carried out is improvements related to the context of the learning process.

Many problems were encountered by teachers in the field, especially during this Covid-19 pandemic, offline learning activities turned into online. Considering the actual conditions that exist in the virtual classroom, CAR Training is needed, according to Carr and Kemmis Model (Kusumah, 2012).

This CAR proposal writing training through community service activities is the most effective and efficient alternative to solving problems PAUD 'Aisyiyah Central Java teachers face. In this activity, the teachers were given counseling, about (1) the importance of conducting classroom action research as self-reflection to improve services to students with problems; (2) training (practice) and direct guidance on how to prepare a class action research proposal; and (3) the time of providing training is carried out during school holidays so that teachers do not need to leave their teaching hours.

\section{METHOD}

CAR Training for PAUD 'Aisyiyah teachers which is a means for teachers to do self-reflection. The various problems encountered in the classroom are fascinating to be used as research materials that require teachers to apply various strategies to improve teacher skills in managing scientific thinking skills. Teachers need to do. To find out the initial conditions, the participants were given a pretest.

Based on the teacher's answers, it was quickly seen that the ability of the trainees to write CAR proposals was very lacking. This community service activity targets all Classroom Action Research proposal participants writing training consisting of 142 PAUD 'Aisyiyah teachers in Central Java. 
Classroom action research proposal writing training in community service activities is divided into several stages, namely: (1) presentation/counseling and guidance, this method is used to explain the ways and steps for preparing class action research proposals accompanied by various examples of proposals, (2) providing training independently there are still many teachers who do not understand the material given asynchronously through WA, VC, telephone applications. Through this application, participants practice compiling research proposals with the guidance of the community service team from UHAMKA. (3) Participants make improvements to the proposal based on input from the community service team. With these activities, it is hoped that the understanding and skills of PAUD 'Aisyiyah teachers in preparing classroom action research proposals will improve.

To help facilitate community service, the tools used are laptops, LCDs, and cameras. The form of evaluation used to determine the level of service success, namely, (1) observation to determine the level of attendance, perseverance, and sincerity, (2) written test, to determine the level of understanding of participants after attending counseling on how to prepare a class action research proposal.

The methods used to provide this training include: (1) 10 minutes before the activity begins, participants are asked to answer pretest questions to determine the participants' ability in writing CAR. Based on the pretest results, information was obtained that only a few participants had ever written CAR. (2) The presentation of the delivery of training materials by the UHAMKA PPM team includes Classroom Action Research theories, case examples, themes worthy of being appointed as CAR proposal titles, and the technical preparation of CAR proposals. This activity was held on June 24, 2021, attended by 142 PAUD teachers using the Zoom Meeting application. (3) Individual tutoring was conducted to help PAUD 'Aisyiyah teachers write Classroom Action research. The training focused on parts of the components in the proposal, starting from writing the title, introduction, simple theories used, and research methods. This is intended to measure the teacher's ability at the time of training. The tasks given are written in the simplest form. When the training participants are considered to have sufficient skills, they are given independent tasks in the form of projects that must be made to support training activities in the form of CAR proposals.

\section{RESULTS AND DISCUSSION}

This training activity is carried out in three stages based on the stages in service activities: preparation, implementation, and evaluation.

\section{The preparation phase}

Community Service Activities begins with preparing activity instruments, preparing material in the form of power points related to CAR, making questionnaires related to responses from PAUD 'Aisyiyah teachers in Central Java, and preparing scientific article assessment instruments. Each team coordinates with related parties to implement activities, so it is agreed that service activities will be carried out on Thursday, June 24, 2021 through a zoom meeting.

\section{Implementation phase}

The writing of a CAR proposal held on June 24, 2021, was attended by 142 PAUD 'Aisyiyah Central Java teachers. The PKM activities consisted of 2 lecturers from the PKM implementation team with the subject of writing a CAR proposal. During the delivery of CAR materials by the PPM team, the training participants were very enthusiastic about listening, asking many questions, and sharing examples of cases they experienced in class during the teaching and learning process. be delivered. During the activity, not a single teacher left the training program until all the activities were completed. At the end of the activity, each teacher is obligated to submit a CAR proposal and is given five days.

\section{Evaluation phase}

Evaluation of program implementation is carried out using a test at the end of the activity so that the implementer gets data about the participants' understanding of the training material provided. In addition, partners monitor participants in their implementation at their respective PAUD institutions. At the end of the training activity, a questionnaire containing 8 (eight) questions was given and a recapitulation of the results is presented in Table 1 . Furthermore, the participants were given homework in the form of compiling a CAR-based scientific article. The article was sent via e-mail to the PKM Team, and an assessment was carried out using the form that has been prepared.

From the questionnaire data, information was obtained that all participants felt the need to take part in the Class Action Research article writing training. In the second question, it can be seen that all participants feel they are not forced to participate in CAR training activities. From the answers to the third question, information was obtained that all the training participants could receive the material explanation well. To the fourth question, all participants answered that the CAR training was beneficial because they could add insight to the participants about CAR. In the fifth question, 8 participants stated that this training was a new thing. From the answer to question no. 6, PPT used in training can facilitate training. For the seventh question, the answer was that the training was helpful, and the answer to question number 8, participants hoped that further training activities would be held from writing CAR proposals. 
Table 1. Responses of training participants for classroom action research proposal writing

\begin{tabular}{|c|c|c|c|c|}
\hline No. & Question & Yes & No & Abstain \\
\hline 1. & Do you need this training? & $\sqrt{ }$ & & \\
\hline 2. & Do you feel compelled to participate in this activity? & & $\checkmark$ & \\
\hline 3. & Can you pick up the explanation of the speaker well? & $\checkmark$ & & \\
\hline 4. & Was this activity useful? & $\checkmark$ & & \\
\hline 5. & Is the material given new to you? & $\checkmark$ & & \\
\hline 6. & Can the training media make it easier for you to comprehend explanations from the presenters? & $\checkmark$ & & \\
\hline 7. & Give your opinion about the implementation of the training activity on writing a PTK proposal & $\checkmark$ & & \\
\hline 8. & What do you think if this kind of activity were to be done again? & $\checkmark$ & & \\
\hline
\end{tabular}

The proposal writing activity lasted for five days. During the making of a Classroom Action Research proposal, each group of training participants can have discussions, but each participant has to make a report for it. In this training activity, a lot of discussions took place between teachers, either through WAG or zoom if needed. At the end of the activity, inputs were given by the PPM team regarding content, writing, and training activities (Figure 1 and Figure 2).

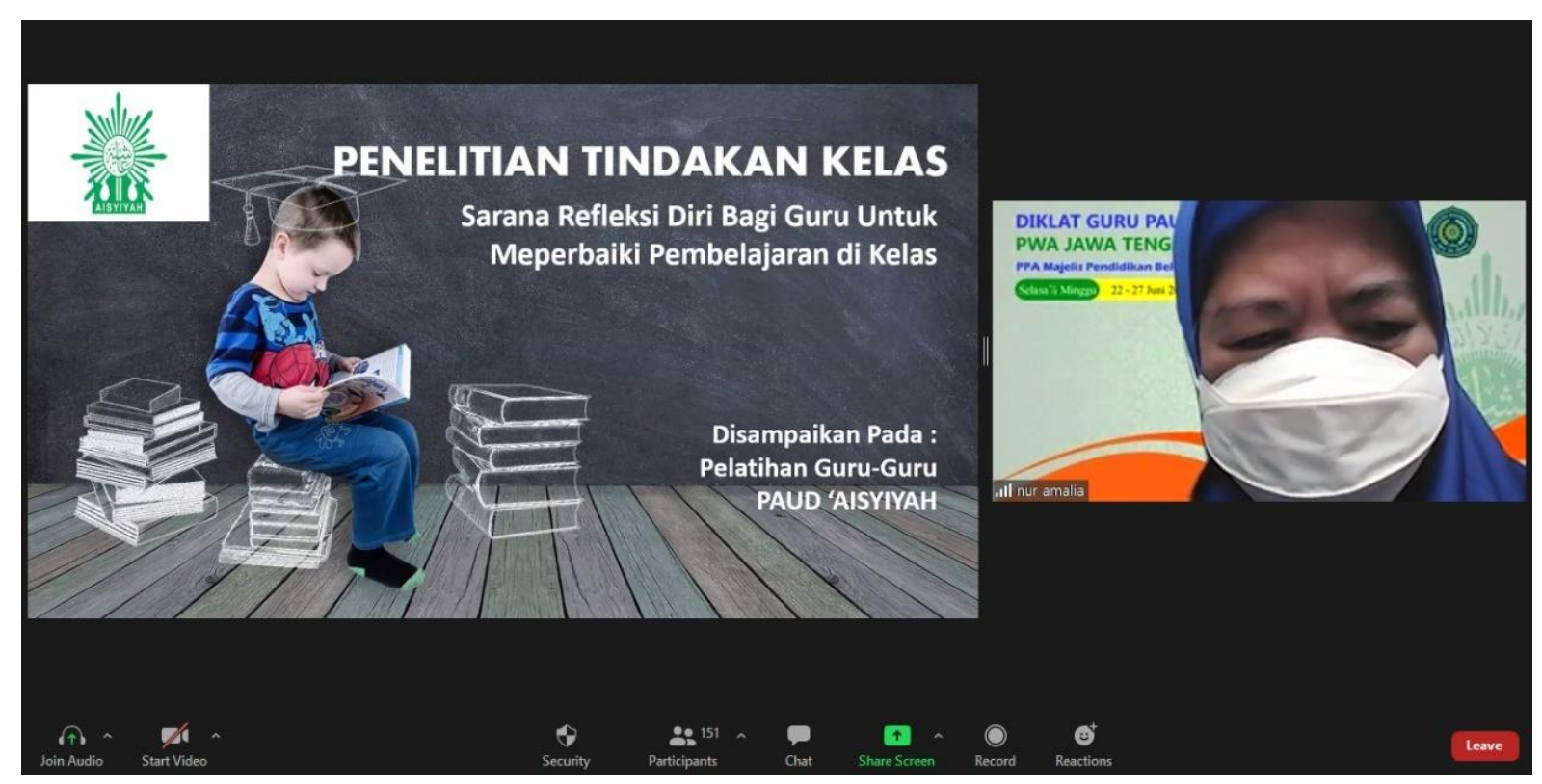

Figure 1. Presentation session

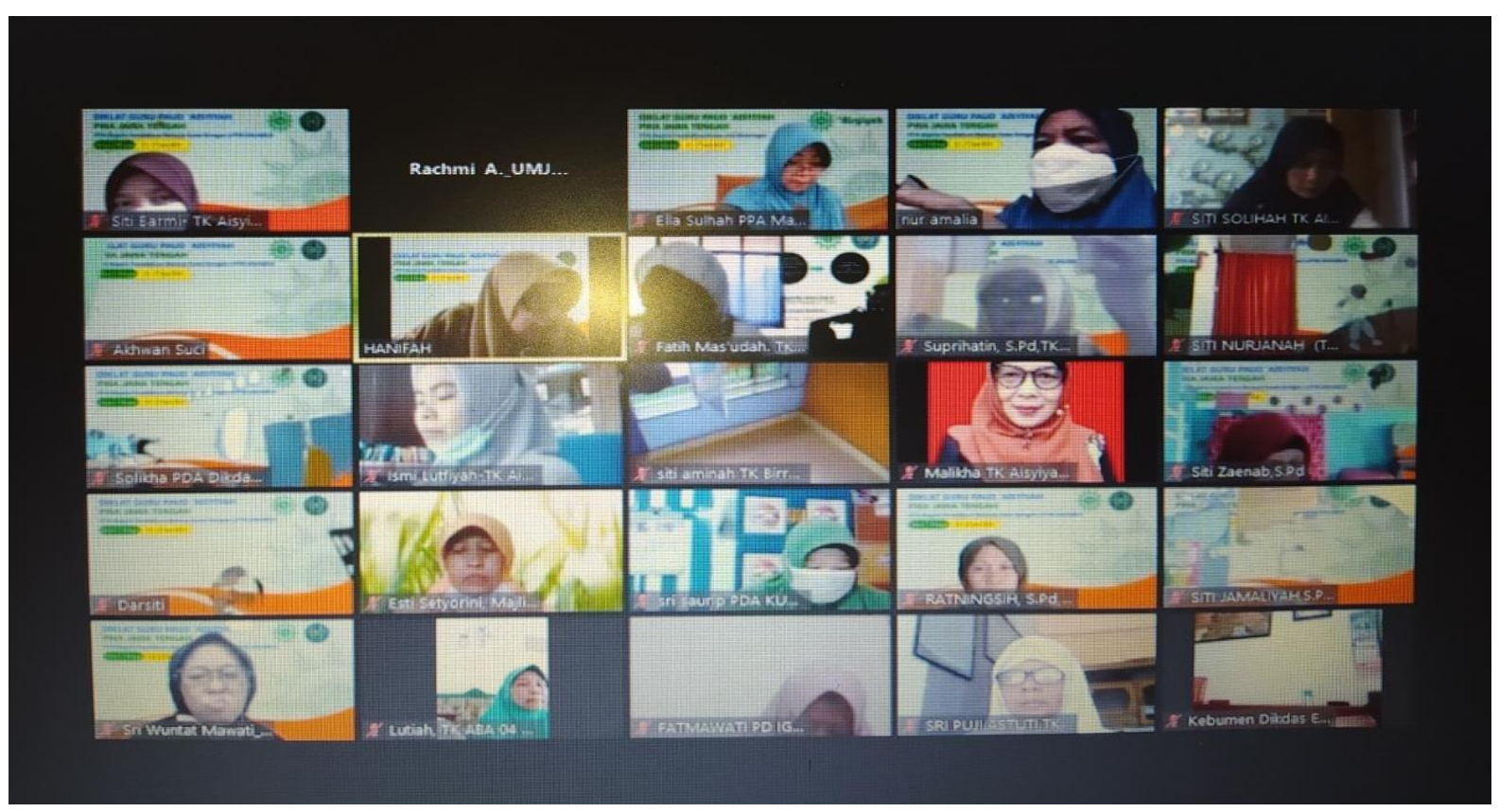

Figure 2. Training participants 
During the CAR proposal writing process, the participants who are actively communicating are given the necessary input. The proposal writing process itself lasted for ten days. During the proposal collection period, a lot of discussions took place via WAG and telephone regarding the content, writing, cases, and references used. This shows the high enthusiasm of the teacher in this activity.

July 4, 2021, is the deadline for submitting Class Action Research proposals. Of the 142 training participants, only 63 people sent their proposals to us for review. After being read carefully, there were only eight proposals that were written in full, the other 30 were still half-heartedly done and did not follow the procedures for writing the CAR. Two people sent the CAR that they had made in 2015 and 2016. When confirmed, the reasons are not having time, many other jobs, not sure about the results of his writing, difficulty in writing down his ideas, afraid of being wrong, the time given is too short.

Teachers are very interested in mastering Classroom Action Research competencies, large and adequate quota facilities for implementing this training process so that this training can run without obstacles, each teacher has a laptop and can access the internet well. The enthusiasm of all teachers to gain valuable new knowledge is very high. Training is carried out when there are no teaching and learning activities. Tremendous support from PWA and the Central Java Province Education and Culture to carry this big event out properly.

From the 63 proposals submitted, information was obtained that the ability of teachers to write Classroom Action Research proposals was still very lacking because many still had difficulty expressing their ideas. There are still many teachers who have difficulty fulfilling the requirements for promotion because one of the requirements that must be met is scientific work. This is reinforced by the fact that some teachers have followed the requirements that must be met to take care of promotions IV/b, no passed, because scientific papers were made, there were still many that had to be revised and needed improvements (Hoogenboom \& Manske, 2012; Kelly et al., 2014). It is clear that scientific work is significant, especially for someone who will carry out professional development both internally and career development for the teacher concerned (Darling-Hammond et al., 2020; Drossel \& Eickelmann, 2017; Lindvall \& Ryve, 2019; Vrasidas \& Glass, 2007).

The number of submitted proposals (63 proposals) was read and noted the parts that needed improvement. The essential thing that needs to be improved is the ability to put ideas into writing, punctuation marks, word choice, and sentence structure that do not meet the requirements of a sentence, making it difficult to understand the meaning conveyed. Likewise, with the use of written language that should be used in CAR, some participants wrote proposals in spoken language, and matters related to the ability to use PUEBI, choice of standard sentence structure words, lack of knowledge about effective sentence writing and standard language in scientific writing. , lack of references and ignorance of how to access references from accredited journal sources, limited training time allocation and not understanding how to access sources from accredited journals, too short training time, less than optimal network during discussions, lack of awareness and responsibility responsible for completing tasks, so that only some of them collect proposals and others only fulfill the requirements and do not maximize the time for consultation outside of training hours.

Seen from the evaluation results based on the participants' responses and questions to the UHAMKA community service team, the responses and questions that indicated interest and curiosity were asked quite a lot by the participants. This can be seen from the parameter table that is evaluated as shown in the Table 2.

Table 5. 1 Participant Response Parameter

\begin{tabular}{clcc}
\hline \multirow{2}{*}{ No. } & Parameters & \multicolumn{3}{c}{ Information } \\
\cline { 2 - 4 } & Mery good & Good & Fair \\
\hline 1. & Material reception & $\checkmark$ & $\checkmark$ \\
2. & Comprehension & & $\checkmark$ \\
3. & Application & & $\checkmark$ \\
\hline
\end{tabular}

The evaluation results were carried out based on the responses and questions submitted by the participants to the UHAMKA community service team. Responses and questions indicating interest and curiosity were asked quite a lot by participants. This can be seen from the parameter table that is evaluated, as shown in Table 2.

Theoretically, this training was successful, this can be seen from the enthusiasm of the trainees who actively asked questions about the problems they encountered related to the steps for preparing CAR proposals, but judging from the results of the practice of preparing proposals, it was not satisfactory because only $15 \%$ of participants were able to prepare CAR proposals with good and 33\% considered sufficient. In comparison, 52\% of participants have not succeeded in compiling a CAR proposal. It is not easy to write CAR; it is necessary to practice independent efforts from the teacher concerned to solve the problems faced in PBM. In general, PAUD 'Aisyiyah Central Java teachers need assistance in writing Classroom Action Research

\section{CONCLUSION}

For this CAR proposal-making training to be achieved as expected, the CAR Training for Aisyiyah PAUD Central Java teachers to improve the quality of learning needs to be carried out precisely, only discussing the writing of supervised CAR. For this reason, it is necessary to make field observations related to the needs of PAUD 'Aisyiyah Central Java teachers per region at the service location in the following years so that the objectives of Community Service Activities 
can be carried out optimally and teachers can write CAR correctly so that there is an increase in quality. education in PAUD 'Aisyiyah Central Java.

\section{REFERENCES}

Agustini, D., Lian, B., \& Sari, A. P. (2020). School'S Strategy for Teacher'S Professionalism Through Digital Literacy in the Industrial Revolution 4.0. International Journal of Educational Review, 2(2), 160-173. https://doi.org/10.33369/ijer.v2i2.10967

Ahmadi, N., \& Besançon, M. (2017). Creativity as a Stepping Stone towards Developing Other Competencies in Classrooms. Education Research International, 2017, 1-9. https://doi.org/10.1155/2017/1357456

Amalia, N., Nawawi, N., \& Puspitasari, N. A. (2021). Training on writing COVID-19 slogans for teens and basic food assistance for angkot drivers affected by the pandemic. Journal of Community Service and Empowerment, 2(1), 35-40. https://doi.org/10.22219/jcse.v2i1.13265

Ananda, R., \& Abdillah, A. (2018). Pembelajaran terpadu: Karakteristik, landasan, fungsi, prinsip, dan model. Lembaga Peduli Pengembangan Pendidikan Indonesia.

Darling-Hammond, L., Flook, L., Cook-Harvey, C., Barron, B., \& Osher, D. (2020). Implications for educational practice of the science of learning and development. Applied Developmental Science, 24(2), 97-140. https://doi.org/10.1080/10888691.2018.1537791

Drossel, K., \& Eickelmann, B. (2017). Teachers' participation in professional development concerning the implementation of new technologies in class: a latent class analysis of teachers and the relationship with the use of computers, ICT self-efficacy and emphasis on teaching ICT skills. Large-Scale Assessments in Education, 5(1). https://doi.org/10.1186/s40536-017-0053-7

Hoogenboom, B. J., \& Manske, R. C. (2012). How to write a scientific article. International Journal of Sports Physical Therapy, 7(5), 512-517. https://pubmed.ncbi.nlm.nih.gov/23091783

Kamamia, L. N., Ngugi, N. T., \& Thinguri, R. W. (2014). To establish the extent to which the subject mastery enhances quality teaching to student-teachers during teaching practice. International Journal of Education and Research, 2(7), 641-648.

Keiler, L. S. (2018). Teachers' roles and identities in student-centered classrooms. International Journal of STEM Education, 5(34), 1-20. https://doi.org/10.1186/s40594-018-0131-6

Kelly, J., Sadeghieh, T., \& Adeli, K. (2014). Peer Review in Scientific Publications: Benefits, Critiques, \& A Survival Guide. EJIFCC, 25(3), 227-243. https://pubmed.ncbi.nlm.nih.gov/27683470

Khasinah, S. (2013). Classroom Action Research. Jurnal Pionir, 1(1), 33-61.

Kusumah, W. (2012). Mengenal Penelitian Tindakan Kelas. Indeks. http://kin.perpusnas.go.id/DisplayData.aspx?pld=93245\&pRegionCode=UN11MAR\&pClientld=112

Lateh, A., Waedramae, M., Weahama, W., Suvanchatree, S., Yeesaman, N., Buathip, S., \& Khuhamuc, S. (2020). Developing Action Research Model for Thai Tertiary Classrooms. International Journal of Instruction, 14(1), 567586. https://doi.org/10.29333/IJI.2021.14134A

Lindvall, J., \& Ryve, A. (2019). Coherence and the positioning of teachers in professional development programs. A systematic review. Educational Research Review, 27, 140-154. https://doi.org/https://doi.org/10.1016/j.edurev.2019.03.005

Marta, N. (2020). Penelitian tindakan kelas sebagai upayanpeningkatan profesionalisme guru sejarah di sekolah menengah atas Kabupaten Bogor. Sarwahita : Jurnal Pengabdian Kepada Masyarakat, 17(1), 22-29.

Nurdyansyah, N., \& Fahyuni, E. F. (2016). Inovasi model pembelajaran sesuai kurikulum 2013. Nizmania Learning Center.

OECD. (2018). The future of education and skills: Education 2030. In OECD Education Working Papers. https://doi.org/10.1111/j.1440-1827.2012.02814.x

Oktoviana, L. T., Hasanah, D., Sulandra, I. M., Susiswo, S., Lestari, T. E., \& Nurhakiki, R. (2020). Pendampingan Penulisan Artikel Ilmiah dari Hasil Penelitian bagi Guru Matematika SMK Kota Kediri. Abdimas: Jurnal Pengabdian Masyarakat Universitas Merdeka Malang, 5(2), 115-122. https://doi.org/10.26905/abdimas.v5i2.3820

Paul, J., \& Jefferson, F. (2019). A comparative analysis of student performance in an online vs. face-to-face environmental science course from 2009 to 2016. Frontiers in Computer Science, 1, 7. https://www.frontiersin.org/article/10.3389/fcomp.2019.00007

Remesh, A. (2013). Microteaching, an efficient technique for learning effective teaching. Journal of Research in Medical Sciences: The Official Journal of Isfahan University of Medical Sciences, 18(2), 158-163. https://pubmed.ncbi.nlm.nih.gov/23914219

Sabilah, F., Abidasari, E., \& Husamah, H. (2021). Teacher professional education coaching to produce high quality lesson plan. Journal of Community Service and Empowerment, 2(1), 13-21. https://doi.org/10.22219/jcse.v2i1.15905

Serdyukov, P. (2017). Innovation in education: What works, what doesn't, and what to do about it? Journal of Research in Innovative Teaching \& Learning, 10(1), 4-33. https://doi.org/10.1108/jrit-10-2016-0007

Stanciu, C., Coman, C., Gabriel, T., \& Bularca, M. C. (2020). Online Teaching and Learning in Higher Education during the 
Coronavirus Pandemic: Students 'Perspective. Sustainability, 12, 10367.

Sumiati, E., \& Wijanaraga, I. W. (2020). How Do Librarians Serve Users In Digital Literacy Era? Case Study at Governance Institute of Home Affairs. Indonesia Journal of Librarianship, 1(1), 33-43.

Sunardi, S., Sujadi, I., Winarni, E. W., \& Suryanti, S. (2017). Sumber Belajar Penunjang Plpg 2017: Kompetensi pedagogik. Kementerian Pendidikan dan Kebudayaan: Direktorat Jenderal Guru dan Kependidikan.

Supriyanto, A. (2017). Peningkatan kemampuan guru dalam penulisan karya ilmiah melalui pelatihan penelitian tindakan kelas. Abdimas Pedagogi, 1(1), 1-7.

Syah, M. N. S. (2016). Classroom Action Research As Professional Development of Teachers in Indonesia. Journal Tarbawi, 13(1), 1-16. https://ejournal.unisnu.ac.id/JPIT/article/view/526

Trust, T., Krutka, D. G., \& Carpenter, J. P. (2016). "Together we are better": Professional learning networks for teachers. Computers \& Education, 102, 15-34. https://doi.org/10.1016/j.compedu.2016.06.007

Ulianas, A., Azhar, M., Yusmaita, E., Prabuntari, H., \& Effendi, E. (2018). Pelita Eksakta. Pelita Eksakta, 2(1), $22-27$. https://doi.org/10.24036/pelitaeksakta/vol2-iss1/49

Unesco. (2016). Unpacking Sustainable Development Goal 4: Education 2030; guide - UNESCO Biblioteca Digital. https://www.campaignforeducation.org/docs/post2015/SDG4.pdf

Usman, J., Mawardi, M., \& Husna, H. (2021). Progresif Developing the Textbook of Classroom Action Research Through. Jurnal Pendidikan Progresif, 11(1), 1-11. https://doi.org/10.23960/jpp.v11.i1.202101

Vrasidas, C., \& Glass, G. V. (2007). Teacher professional development and ICT: Strategies and models. Teachers College Record, 109(14), 87-102. https://doi.org/10.1111/j.1744-7984.2007.00116.x

Wahyono, P., \& Husamah, H. (2020). Guru profesional di masa pandemi COVID-19: Review implementasi, tantangan, dan solusi pembelajaran daring. Jurnal Pendidikan Profesi Guru, 1(1). https://doi.org/10.22219/jppg.v1i1.12462

Wahyudin, D. (2018). Peace education curriculum in the context of Education Sustainable Development (ESD). Journal of Sustainable Development Education and Research, 2(1), 21. https://doi.org/10.17509/jsder.v2i1.12354

Wijayati, N., Sumarni, W., \& Supanti, S. (2019). Improving Student Creative Thinking Skills Through Project Based Learning . KnE Social Sciences, 3(18 SE-Articles). https://doi.org/10.18502/kss.v3i18.4732

Wollman-Bonilla, J. E., Husbands, C., Pearce, J., Taylor, L. K., Bernhard, J. K., Garg, S., \& Cummins, J. (2008). What makes great pedagogy ? Nine claims from research Autumn 2012 Great pedagogy : nine claims from research. Journal of Early Childhood Literacy, 8(3), 167-192.

http://ecl.sagepub.com/cgi/doi/10.1177/1468798408096481\%5Cnhttp://ecl.sagepub.com/cgi/content/abstract/ $1 / 2 / 167$

Yakub, P., Puspitawati, R. P., \& Bashri, A. (2021). Developing analytical skills through optimizing the learning process by science teachers in Nganjuk Regency. Journal of Community Service and Empowerment, 2(2), 77-82. https://doi.org/10.22219/jcse.v2i2.16750

Yuan, X., Yu, L., \& Wu, H. (2021). Awareness of sustainable development goals among students from a chinese senior high school. Education Sciences, 11(9). https://doi.org/10.3390/educsci11090458 